\title{
Collaborative Designing of Communities. Helsinki and Zurich Pioneers
}

\author{
Virginia De Jorge-Huertas ${ }^{1}$ \\ Received: 2019-11-04 | in its final version: 2020-02-14
}

\begin{abstract}
High costs of housing, duality of tenancy generating the impossibility to access adequate housing, a high expenditure of salary dedicated to rent and building design not linked to the real needs of the users are causing an urgent search for alternative housing models. The empirical research presented in this article is intended to identify alternative housing management and spatial distribution through democratic design in an era of shortage in affordable housing provision. The article focuses on two pioneers' case-studies: "Casa Malta", a multigenerational cohousing in Helsinki and "Genossenschaft Kalkbreite", a non-profit hybrid cooperative in Zurich, both developed in 2010 decade. The main key points analysed are the human-centred design through participative processes, the shared spaces and the housing policies adopted. These two projects highlight their ability to create an affordable model for urban development perceiving housing as a collective process, affordable living, gender equality and reducing the speculation in housing as basic need. This research aimed to identify the key points of these alternative approaches for housing.
\end{abstract}

Keywords: architecture of participation; collaborative housing; citizen participation; shared spaces

Citation

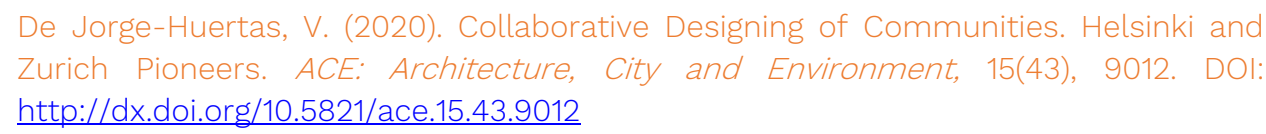

${ }^{1}$ Architect, Ph.D., Postdoctoral Researcher, Dipartimento di Culture del Progetto, Università IUAV di Venezia (ORCID: 0000-0002-8698-245X; WOS Researcher ID: Q-4344-2019; Scopus Author ID: 57190685681) Contact e-mail: virginiadjh@gmail.com

\section{Introduction}

Standardised collective housing does not seem to satisfy and is unable to adapt to the current needs and desires of society. Moreover, housing needs vary over an individual's lifetime. Consequently, collaborative housing is currently widespread in housing research because it offers alternatives to different society needs, from affordable rents, sustainability features, gender-based urbanism (Hayden, 1980; Sanchez de Madariaga and Roberts, 2016), participation of female architects (CarreiroOtero and López-González, 2019) and gender equality in the burden of housework (Horelli and Vepsä, 1994) to high-end senior cohousing projects. These approaches can be observed internationally (Vestbro and Horelli, 2012; McCamant and Durrett, 1994; Droste, 2015; Jarvis, 2015; Sandstedt and Westin, 2015; Boonstra, 2016; Verhetsel et al., 2017; Hofer,2017; Gutzon and Jakobsen, 2018; Lang et al., 2018). Whether traditional, rehabilitation of large housing estates (Díaz et al., 2019) or retrofit (Sanguinetti, 2015; De Jorge-Huertas, 2018b), cohousing provides social, economic, and environmental sustainability and contributes to a better quality of life (Verhetsel et al., 2017). 


\subsection{European collaborative housing framework}

In Europe, many different initiatives are emerging related to cohousing, self-made managed construction and cession of use cooperatives, as can be observed in the initiators in Denmark (Falkenstjerne Beck, 2019), Sweden (Vestbro, 2000, 2012), France (Bresson and Denèfle, 2015), Germany (Droste, 2015; De Jorge-Huertas, 2019b) and the Netherlands (Tummers, 2015). Meanwhile, a new generation of cohousing initiatives can be found in Spain, as "Entrepatios" in Madrid, the retrofit cohousing in Calle Princesa or the wood-prototype La Borda, both in Barcelona (Cabré and Andrés, 2018), strongly capillary in all Catalonia (Parés et al. 2017) as show in the communing housing map (http://commoninghousing.net/cophab-map/, 2020), or in Italy with the first mapping by Housing Lab (Rogel et al., 2018). Regarding the affordability, cohousing initiatives are emerging in Southern Europe to respond to the economic crisis (Marcuse and Madden, 2016) and, therefore, as affordable housing initiatives; while in Norther Europe could be more related to a choice of lifestyle.

The case-studies analysed in this research are based on a cession-of-use non-profit cooperative. This approach is based on models such as the "andelsbevægelsen" (Andel model) or the share movement in Denmark, the FUCVAM in Uruguay, the Sostre-Cívic in Catalonia with pioneers' examples in Spain as La Borda project (La Col y la ciutat invisible, 2018) or the Wohnprojekte model in Germany. These initiatives have been also possible thanks to a committed urban governance (Parés et al, 2017; Scheller and Thörn, 2018). Consequently, cohousing research is being expanded, and it needs further qualitative and quantitative analysis to inspire new projects and policies in different scales.

\subsection{Five-classification system}

According to Horelli and Vepsä (1994), there are different forms of cohousing in terms of number of activities and formal or informal economy. These types can be listed in a five-classification system (Figure 1): A) a well-functioning housing area with a neighbourhood composed of traditional houses and meeting spaces, B) a community of about 8 to 30 householders with $5 \%$ to $20 \%$ of shared spaces, C) a collective dwelling or "big family" composed of 5 to 20 persons where only sleeping units are private and the rest is in common, D) a service house community as an improvement of the first cohousing models thanks to a better interconnection of the "private units" within the shared spaces, not separated but integrated, and E) a working community (e.g. the Kibbutzim).

Figure 1. Five different models of housing ( $A$ to $E$ )

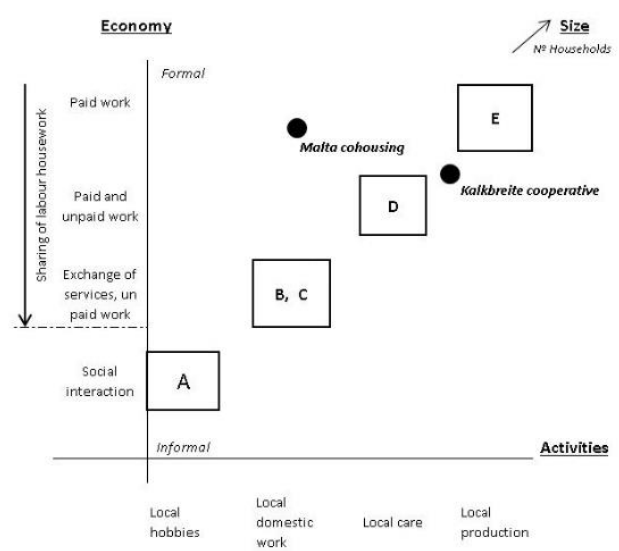

Source: Diagram redrawn considering Horelli and Vepsä (1994, p. 211) and adapted to the case-studies including size (Number of households in the -diagonal-axis) by the author (2019). The different models of housing (A to E) are shown in terms of number of activities in the horizontal-x-axis, formal and informal economy in the vertical $-y-$ axis and size or number of households in the -z-axis.

ACE, 15 (4.3) CC BY-ND 3.0 ES | UPC Barcelona, Spain | Collaborative Designing of Communities. Helsinki and Zurich 2 Pioneers. DOI: http://dx.doi.org/10.5821/ace.15.43.9012 


\subsection{Two case studies: Kalkbreite in Zürich and Casa Malta in Helsinki}

This article aims to analyse two collective housing projects, while describing their advantages and extracting valuable strategies in a multi-scalar framework by identifying the key points of their alternative approaches to housing. These projects are the multigenerational cohousing at Casa Malta in Helsinki and the Kalkbreite cooperative in Zurich. Both are collaborative housing pioneers' projects on how to solve affordability problems and the lack of adaptable shared spaces to the contemporary everyday life. The case-studies were chosen according to their city policies for sustaining housing affordability, avoiding land speculation, and supporting user participation. The expected outcome of this study is a better understanding of the benefits of cohousing with its different dimensions.

This article presents the results of an empirical research of two case-studies, the first is located in Finland and the second is located in Switzerland. Both projects reflect different approaches to the contemporary collaborative way of life and urban innovation: the age-integrated cohousing type (Sandstedt and Westin, 2015) is used at "Casa Malta" in Helsinki, while the non-profit hybrid cooperative is used in the Genossenschaft Kalkbreite in Zurich. Collaborative housing was first developed in 1960 in Denmark as the Bofællesskabet and in Sweden as the Kollektivhus. Since the 1980s, the complexity and three-dimensionality in architecture have been focalised in two ways: the first was continuing to accept dispersion and the second was to search for a complex mega-object or mega-form as part of an urban landscape (Frampton, 1999).

The case-studies in this research are a "mega-form," which is intended as a high-rise, compact microcity in the city. Therefore, these projects could be seen to have roots in the Swedish Kollektivhus and in the Medium or High-rise High density. This model of collaborative housing is defined by an urban core that is free from the presence of gated communities. It also focuses on the intergenerational collaborative housing subtype, which promotes diversity in a broad sense and is intergenerational in terms of social cohesion. Collaborative housing has been defined as a form of shared collective housing that is based on many different factors. In this research, these factors, derived from the case-studies, are: shared spaces, integrated neighbourhood design, location in an urban area, a participatory process that is based on citizen's involvement, resident-led partial or full management, and non-hierarchical decision making.

\subsection{Research paper structure}

To address the research aim, the methodology of the research will be explained first. This will be followed by Section 3, which will examine the two case-studies. Section 4 will compare the casestudies in three subsections: spatial flexibility, shared spaces and housing policies. Finally, the main conclusions will be discussed.

\section{Research design and methodology}

\subsection{Criteria for the selection of the case studies}

Both case studies were selected according to their descriptive and analytic characteristics. First, they were both built within the same timeframe (2005-2015), which will allow us to compare construction or structural systems in parallel. Both case studies have been built in cities with housing policies related to alternative tenancies umbrellas. In addition, they have both been developed in a participative process, or "citizen control" (Arnstein, 1969), from the very first moment. Consequently, they have not followed a traditional development project process: The Zurich case emerged from a

ACE, 15 (4.3) CC BY-ND 3.0 ES | UPC Barcelona, Spain | Collaborative Designing of Communities. Helsinki and Zurich

Pioneers. DOI: http://dx.doi.org/10.5821/ace.15.43.9012 
citizen movement and the Helsinki case emerged from a group that used their own effort and money to develop the project. This means that both cases have a bottom-up approach to architecture in countries where this is promoted and regulated though plot leases and right to housing policies.

\subsection{Fieldwork and interview details}

The literature review and fieldwork done between September 2015 and January 2019 were essential to study the actual conditions of the infrastructure and to analyse the buildings' evolution in terms of the citizens' real needs, adaptation to the context and changes related to users' needs and use. Consequently, we made on site architectonical visits to both projects. A guided visit was made to the case in Zurich in 2015 and I visited the case in Helsinki on my own in 2019. In the first case, the interviews were conducted in the form of non-structured dialogues with residents and later by email with the communication managers. In the second case, a face-to-face semi-structured interview was conducted on site inside the cohousing with the leader of the building group of the cohousing to understand its implementation phases.

\subsection{Observation and visual art techniques}

Both case studies have been analysed by developing qualitative methods based on observation and visual art techniques (Bagnoli, 2009) and on image-based research (Prosser, 2008). Specifically, drawings and analytical diagrams were used to graphically represent the field work. Four types of drawings based on image-based research have been made: 1) a constellation or network diagram (Figures 3, 5 and 7), which was used to analyse the interrelated spheres, to show the complexity of the different actors involved to develop this kind of project and to represent the participative process; 2) a conceptual descriptive diagram located on the urban scale (Figures 2, and 4), which was used to analyse if the project is inserted in the centre or in the periphery of the city; 3) an organisation diagram or plan (Figures 4, 6, 8, 9 and 10) of the interior spaces of both architectures; and 4) a classification system diagram (Figure 1), which was used to understand at which level they are established.

\section{Housing alternatives: A hybrid cooperative and a multi-generational cohousing}

\subsection{Case-study 1: The case of the Kalkbreite cooperative in Zurich}

\subsubsection{Zurich context}

Switzerland is characterised by a low rate with a 38\% percentage (FSO, 2017) of home ownership. According to Werczberger (1997), this is due demographic change, public policies, high housing costs, lack of affordable alternatives, and high cost of ownership.

In Zurich, about twenty percent of all housing is owned by cooperatives. According to Balmer and Gelber (2017), Zurich is the only Swiss city that has kept public involvement strategies to provide affordable housing. Furthermore, the non-profit housing cooperatives remain significantly supported through ground leases. In the Kalkbreite case-study, the council granted a lease on the cityowned land, a 95-year lease under building laws (Author Fieldwork 2015; Hediger, 2019). In Figure 2, the following examples are situated on a map of Zurich. The largest building cooperative in Zurich is the Regina-Kägi-Hof (Hofer, 2017). The 2017 "Baffa Rivolta" winner project 'Mehr als Wohnen' was launched to celebrate one hundred years of collective housing in Zurich. This is an association of

ACE, 15 (4.3) CC BY-ND 3.0 ES | UPC Barcelona, Spain | Collaborative Designing of Communities. Helsinki and Zurich 
several cooperatives, which is run together with the city of Zurich. The success of the cooperative housing in Switzerland is explained by Balmer and Gerber (2017) as being due to two factors: first, it is based on housing policies on private initiative rather than public property; and second, it targets the middle class. In the cooperative, there is no space for speculation (Hofer et al., 2015). In 2020, another initiative in the same form as the Kalkbreite cooperative will be developed in Zollstrassethe "Das Zollhaus" (The Custom House) will be designed by the architect Evelyn Enzmann (Enzmann Fischer architects), the second property of the Genossenschaft Kalkbreite (see Figure 2) will be used for dwellings.

\subsubsection{The Kalkbreite non-profit cooperative}

Since 1978, the Kalkbreite area (Figure 2) has been required to develop cooperative housing from civil establishments recognised by Zurich municipality council (Ibrahim and Müller, 2014). At that time, the area was occupied by VBZ tram depots. In 2000, the Federation of Cooperative Housing in Switzerland (Charta der gemeinnützigen Wohnbauträger in der Schweiz) reactivated a cooperative approach to housing with the support of politicians and non-profit housing cooperatives. To promote the quality of life, an agreement for housing policies was made that focussed on participation, the environment, integration of different social generations, and non-speculative profits.

Figure 2. Urban location of the Zurich case-studies
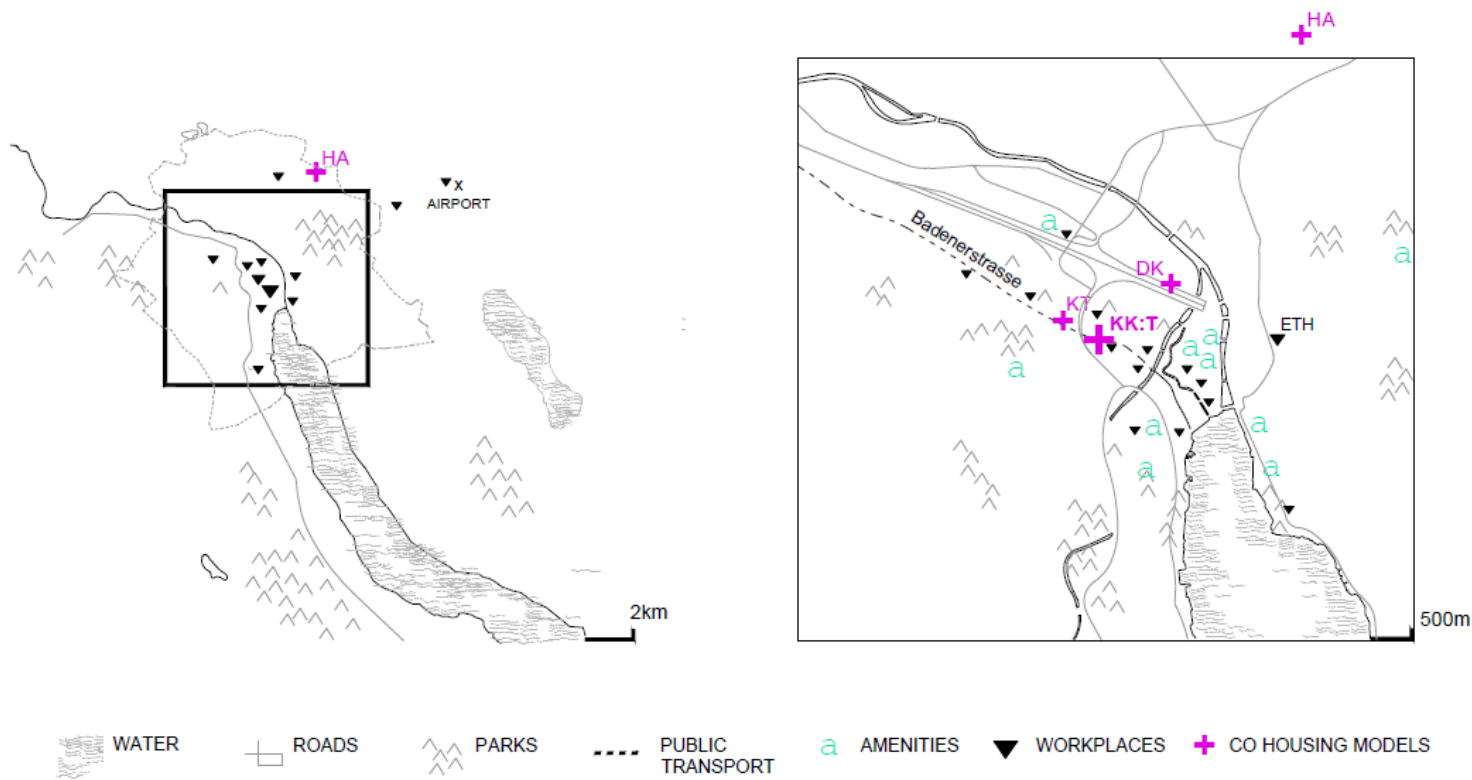

The acronyms are: Cooperative Karthago (KK), Kalkbreite (KT), Regina-Kägi-Hof (RK), Hunziker Areal or Mehr als Wohnen (HA), and Das Kollhaus (DZ). Source: Line drawing by the author.

Figure 3 shows the different actors and references, which explain the interdisciplinary Kalkbreite process. In this Figure 3, the literature review on the cooperative movement is shown in the second biggest circle and network agents of Kalkbreite are shown in the biggest circle into the participative process. In the Figure 3 different spheres are drawn: Kalkbreite coop, Cooperative movement and Zurich City with Ursula Koch who stated: Die Stadt ist gebault! (The city is built!). The sphere "Mehr als Wohnen", which won the Baffa Rivolta, and the other projects spheres (Karthago, the future Das Kollhaus) are showing the existing cooperative network in Zurich. The multidisciplinary approach is drawn with its different influential circles, and unidirectional or multidirectional connections related to a socio-anthropological, ecological or political-economic association (different lines used: dot line, continuous line, bold line, et al.), while the icons used (square, triangle, star or circle in different black 
and white pigment) are showing the actors involved (academics, architects, politician, sociologist, etc) and the multidisciplinary adopted. The architecture of participation (De Carlo, 1972) in Kalkbreite follows the top level of the Arnstein ladder (1969) and is an almost full citizen control project. The Kalkbreite involved nine working teams of 50 people each, who managed global decisions. Each group of people took care of several aspects of the final project, such as participation, social mix, indoor space, cluster space, space for children, exterior space, management and central services, sustainable living and commercial spaces (Kalkbreite Cooperative, 10 December 2012).

Figure 3. Constellation of actors-network in Kalkbreite

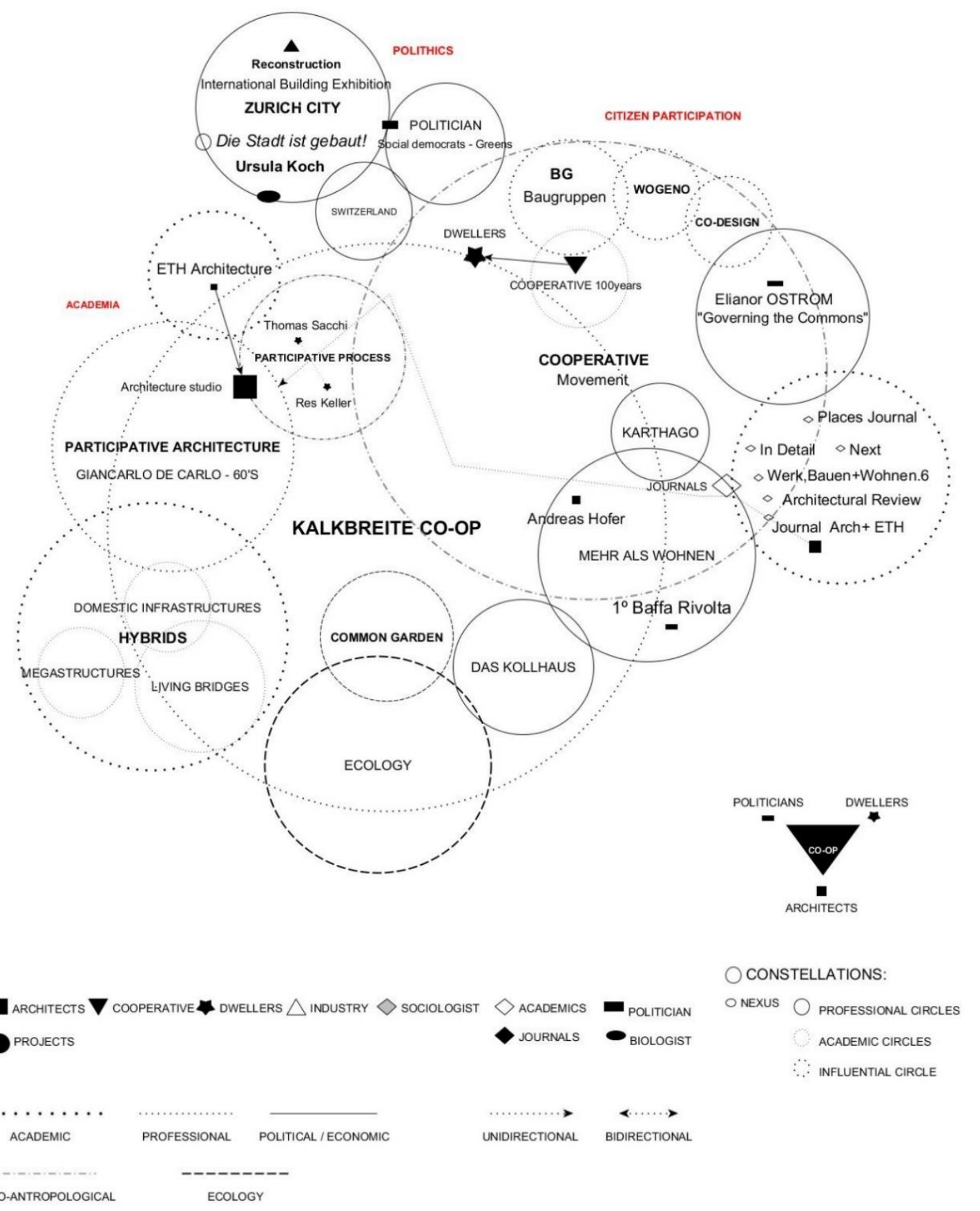

Source: Drawing by the author from literature review and fieldwork.

ACE, 15 (43) CC BY-ND 3.0 ES | UPC Barcelona, Spain | Collaborative Designing of Communities. Helsinki and Zurich 
The Kalkbreite cooperative is similar to previous cooperatives that are also located in Zurich in terms of social and programmatic housing approaches. For example, the Karthago cooperative was created in 1995 as a retrofitting of existing buildings. Another example is the Kraftwerk cooperative, which was developed in 1998 (Boucsein and Seidel, 2015). The Kalkbreite follows a similar approach to the Sargfabrik project in Vienna, which is a non- profit retrofit model that is projected as developing hybrid housing from an old factory.

The Kalkbreite building can be considered as a 'mat-hybrid housing' (De Jorge-Huertas, 2018a), which describes its characteristics and use. "Mat-hybrid housing" consists of a collective building that fulfils the following aspects: 1) it is hybrid because it symbiotically combines housing with other uses differing from residential; 2) it provides a public, private and intermediary level in common space (Horelli and Vepsä, 1994); 3) the building is integrated in a compact attitude, it is not morphologically an urban sprawl; 4) it has common shared spaces; and 5) it is located in urban centres near public transport and urban rhythms.

The building characteristics of the Kalkbreite cooperative is based on a hybrid concept. The elevated park-orchard in the middle is connected to one to eight bedroom-flats. Because the railway is located immediately below the park orchard, the whole building works as an inhabitable bridge, which highlights its hybrid features. A common space is provided in cluster housing of different sizes from level +2.00 to 6.00 on each floor. Other shared spaces (e.g. kitchens, dining rooms, and sauna) are also present and distributed in all floors above level 0.00. The cooperative has also a commercial ground floor and a linear bar with restaurants, a cafe, a micro hostel, a cinema, a flower store in the access area, a bike storage area, a hall, and a foyer.

Social innovation (TEPSIE, 2014) and cohesion, social arrangements and a committed governance related to space distribution is an important topic for the community. Therefore, to improve the community environment, this cooperative provides an "instruction platform", which is an online manual on how to live together (https://anleitung.kalkbreite.net/). The building has a gradual approach to public, semi-public, semi-private and private spaces from the ground floor to the rooftop. The heart of the project is the common park, which is open to the neighbourhood, with hanging gardens and orchards space surrounded by an open street.

\subsection{Case-study 2: The case of the Casa Malta cohousing in Helsinki}

\subsubsection{Helsinki context}

In Helsinki, pioneer projects began to be developed in 1970 with Kuusikylä (Horelli, 2013), which is a cohousing project that was started by 21 families with a common vision of a new everyday life. In the early-2000s, Helsinki experienced rapid growth and it allocated new land for the creation of three new neighbourhoods: Jätkäsaari; Arabianranta, where Tila neo-loft collaborative housing is located (Laine et al., 2019); and Kalasatama. These three areas, as shown in Figure 4, represent creative and cultural neighbourhoods (Sepe, 2014), where the diversity of ownership structures is the key.

The human-centred design (Van der Bijl-Brouwer and Dorst, 2017) and the resident involvement in designing are very important to pursue social integration and the interaction of tenants in their communities. In 2007, the Helsinki association called Hem i stan -Koti Kaupungissa (Home in the City) was founded to promote collaborative collective housing as a social and ecological living based on a construction group. The association has 10 premises, as follows: 1) living next to services and public transport, 2) living near cultural activities, 3) maintaining individual privacy and taking advantage of shared spaces at the same time, 4) promoting shared activities to strengthen togetherness while avoiding loneliness, 5) helping to reach a not-lonely old age, 6) no rigid restrictions, 7) living in a housing

ACE, 15 (4.3) CC BY-ND 3.0 ES | UPC Barcelona, Spain | Collaborative Designing of Communities. Helsinki and Zurich 7 Pioneers. DOI: http://dx.doi.org/10.5821/ace.15.43.9012 
environment where children have trustworthy people near them, 8) taking care of service and shared spaces for hobbies to share together, 9) setting up a domestic space able to adapt to changes in the tenant's needs, and 10) taking advantage of an urban life that is in continuous evolution (Koti Kaupungissa association, 2018).

Following these premises, the multigenerational cohousing project at Casa Malta started to be developing in Jätkäsaari in 2007 (see Figure 5) and was completed in 2013. Casa Malta was the first high-rise multigenerational cohousing in Finland since 1950 (Koti Kaupungissa Association).

Figure 4. Urban location of the Helsinki case-studies
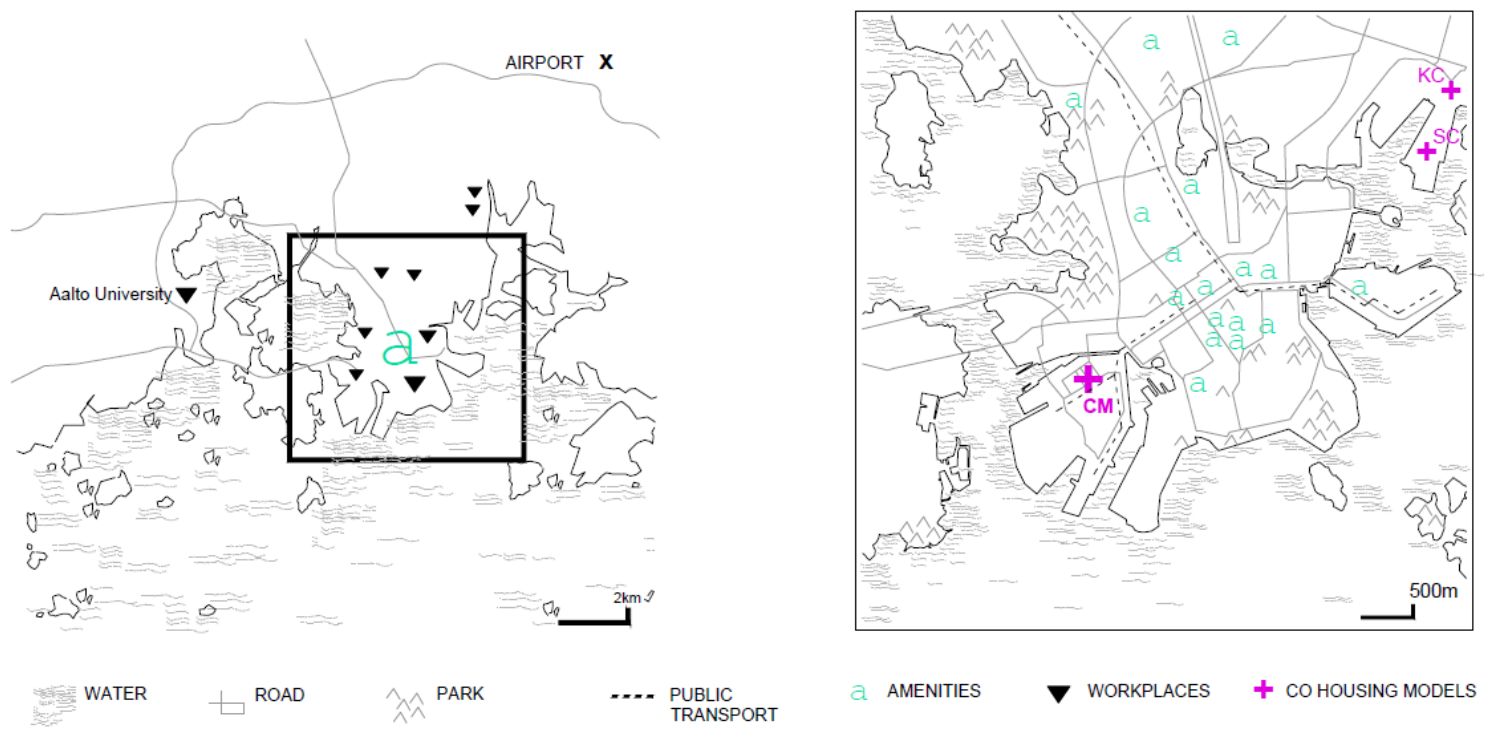

The acronyms are: CM: Cohousing Casa-Malta, SC: Sompasaari Cohousing and KC: Kalasatama Cohousing. Source: Line drawing by the author.

Salla Korpela (2012), who was one of the key figures of Casa Malta project, identifies serving a common ideal, sharing everyday arrangements, and building together as the three main principles at the top of an organisational inner structure of collaborative housing. These concepts are present in the Casa Malta neighbourhood, which is based on planning to share everyday life in a community level. Figure 5 explains the whole constellations, understood as the network project, to be developed Casa Malta. As in the previous example, Malta is also a "citizen control" project. Helsinki is situated geographically in a very interesting area, as shown in the circle in Figure 5. This is related to the cohousing movement, who are pioneers in this kind of new everyday life.

In the Figure 5 the literature review (Phase 1) and network agents (Phase 2 and 3) are shown into the participative process. The figure shows and interprets the context of the Helsinki case-study. It is part of a growing actor-network constellation since it is forged in a collaborative knowledge. A multidisciplinary approach takes part with different influential circles and unidirectional or multidirectional connections related to a socio-anthropological, ecological or political-economic association (different lines used: dot line, continuous line, bold line, et al.) while the icons used (square, triangle, star or circle in different black and white pigment) are showing the actors involved (academics, architects, politician, sociologist, etc.) and the multidisciplinary adopted. Therefore, this case-study works as "pipette" of this complexity and it is an example of supportive infrastructure.

ACE, 15 (4.3) CC BY-ND 3.0 ES | UPC Barcelona, Spain | Collaborative Designing of Communities. Helsinki and Zurich 
Figure 5. Constellation of actors-network in Helsinki

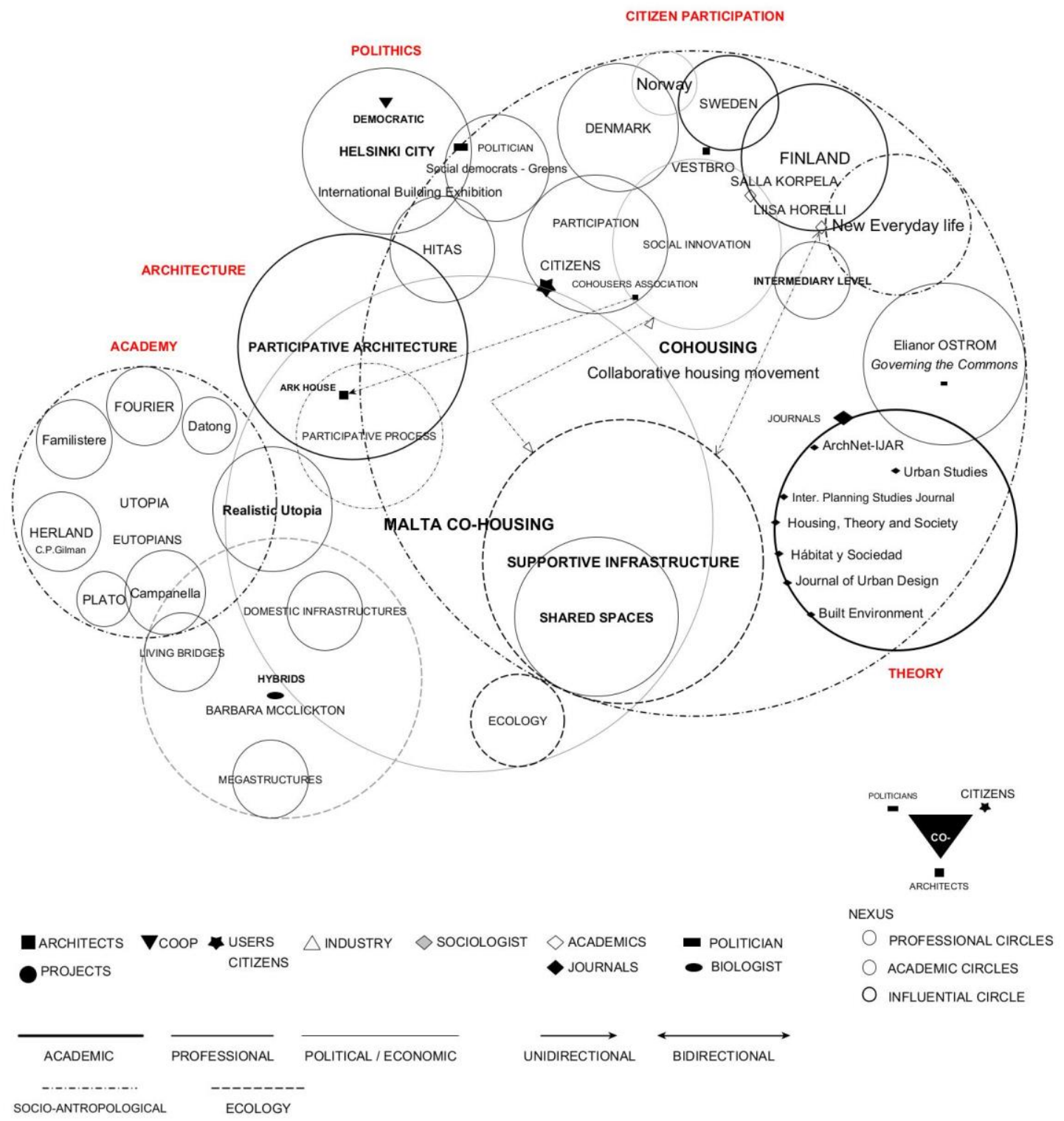

Source: Diagram-drawing by the author from literature review and fieldwork.

\subsubsection{Casa Malta cohousing}

Casa Malta is the largest and most ambitious project in Finland since the 1960s (Laine et al., 2018). It is an intergenerational cohousing project that was designed and constructed between 2007 and 2013. It was promoted, organised and the development risk was taken by all the members, as can be seen in the constellation in Figure 5. It was co-designed with Ark House architecture studio (Figure 6).

Casa Malta is a 61-family owner-based project and co-development that is located in the new urban neighbourhood Jätkäsaari, on a plot that has been leased for 60 years. The shared spaces are on the ground floor (Figure 6) and on the rooftop. The 61 apartments are located between the second and the penultimate floors. The surface area of the apartments varies from 30 square meters to 150 in a two-storey dwelling.

ACE, 15 (4.3) CC BY-ND 3.0 ES | UPC Barcelona, Spain | Collaborative Designing of Communities. Helsinki and Zurich 


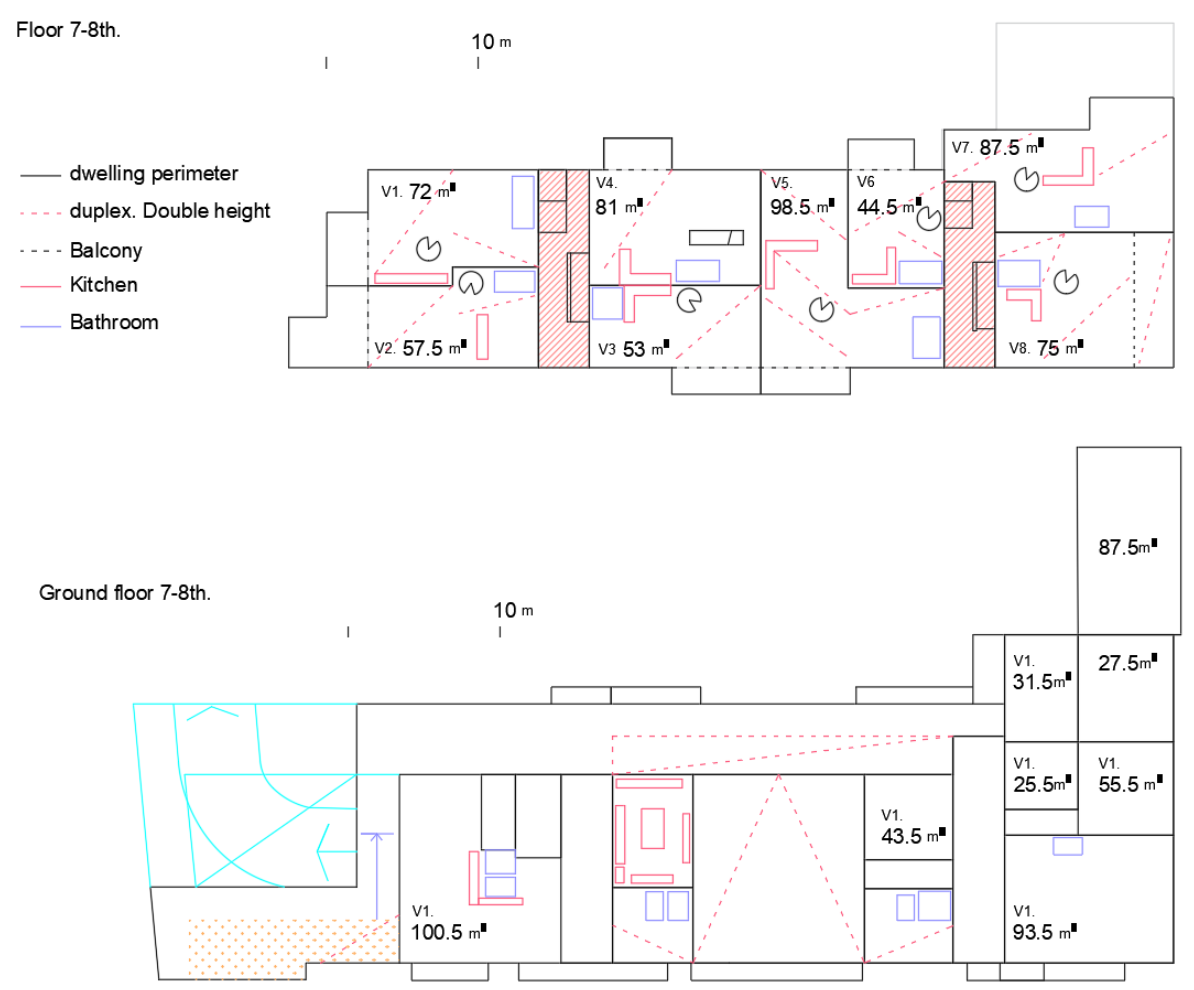

Source: Line drawing by the author from Korpela 2012 (p.338) and fieldwork in January 2019.

Salla Korpela (2017) concludes that group construction aims to increase affordable housing. Group construction means gathering people to project together, who then hire a consultant to manage the building process. The governance and the social arrangements in this case study are based on a horizontal model. Helsinki has set the target of increasing group building as a housing policy because it might recapture traditional construction companies and reduce cyclical fluctuations in housing production.

In terms of the building characteristics and adaptation to the context requirements, Casa Malta's exterior resembles a Tetris game or a giant patchwork game, which follows the tenants' wishes to live in a harmonious way. The perimeter of the building resembles a folded puzzle, while the front façade is a regular grid with vertical stripes and a cluster of balconies.

From an administrative point of view, one important aspect of Casa Malta cohousing (and Finland context) is that its housing policy is based on the 'Hitas owner-occupied housing' and the 'right-ofoccupancy housing', which is an intermediary system between rental and an owner-occupied flat. Hitas is a Helsinki-based home price and quality system that aims to ensure that house prices are based on their real production costs' (Helsinki city). There are currently several ongoing cohousing projects in Helsinki that have been developed following the "Hitas concept", such as the Sompasaaren Sumppi project in Sompasaari and the Kalasataman Messi project located in Verkkosaaren (De JorgeHuertas, 2019). The Kalasataman project is being developed by the Sarlin+Sopanen architecture studio, with a rental period of 60 years. Both of these projects will be built between 2018 and 2020 . 


\section{Results and discussion: Comparing the two case-studies}

After briefly describing the context, history and characteristics of both projects, a comparison is needed to learn from the alternative housing strategies that have been adopted in Helsinki and Zurich. The aspects to be compared, as shown in figure 7, are among the basic concepts of collaborative housing, including housing policies, governance, shared spaces, and spatial flexibility. These three aspects are interrelated since the existence of "new" or at least "alternative" housing policies allow to have shared spaces and spatial flexibility.

The figure 7 shows the housing policies and alternative tenure models, spatial flexibility and shared space. The different lines used (dot line, continuous line, bold line, et al.) are related to the legend (structure, ecological approach, gender-based urbanism if applicable and management model).

Figure 7. Concept diagram supporting case-studies

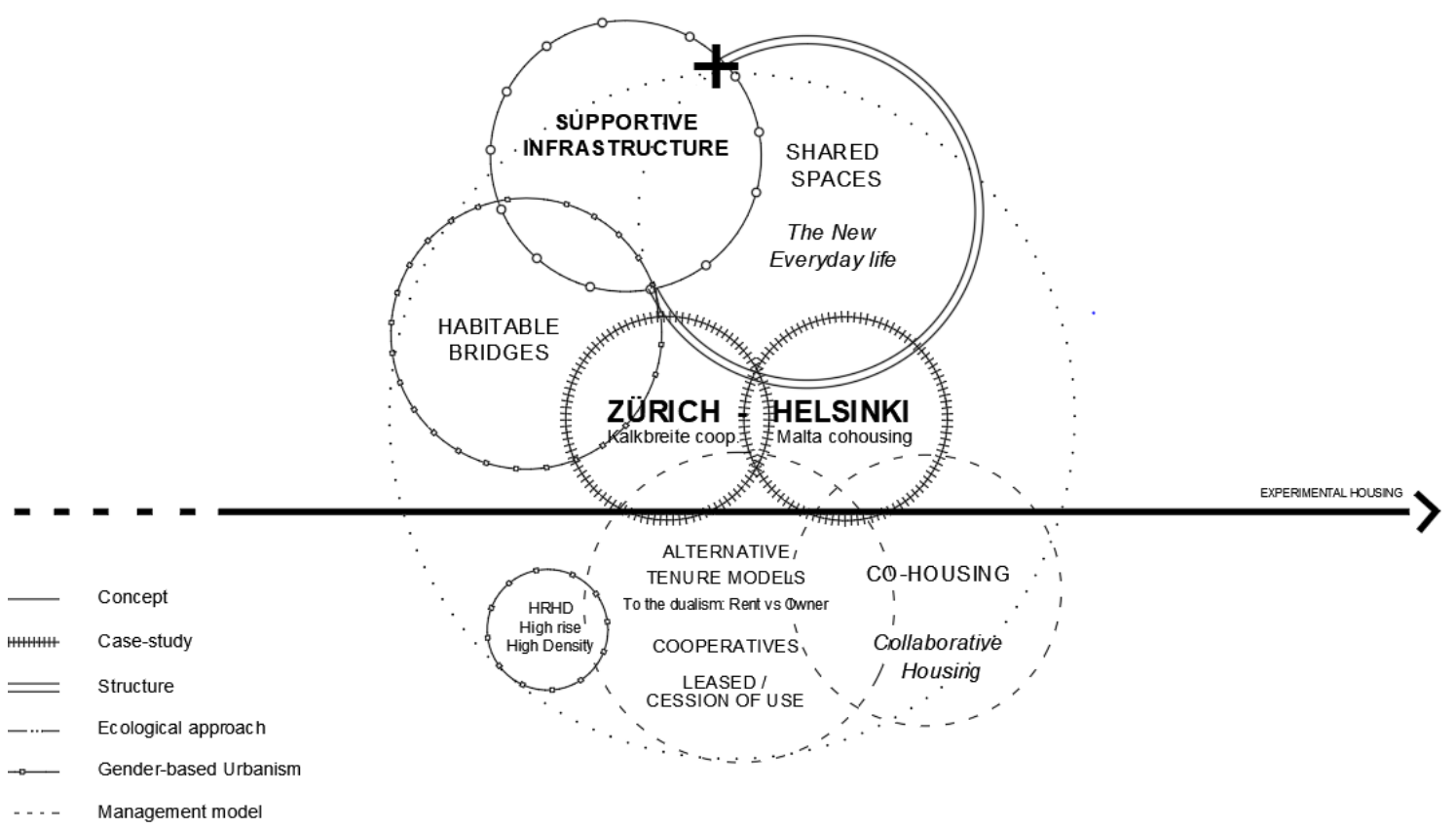

Source: Drawing by the author.

\subsection{Housing policies implemented in Helsinki and Zurich}

The Kalkbreite project required nine working teams of 50 people each to manage global decisions in an interdisciplinary workflow, as shown in figures 3 and 5. Each group of people took care of several aspects of the final project, such as participation, social mix, indoor space, cluster space, space for children, exterior space, management and central services, sustainable living and commercial spaces (Kalkbreite Cooperative, 20 November 2015). The result was a response to changing demographics and the developing of multiple household configurations in a 62-year lease on cityowned land, which was granted by the municipal authorities. Casa Malta also has a plot that is leased for 60 years. The key point of the housing policy in both projects is the tenants' participation at different gradients of "designing with" (Arnstein, 1969; De Carlo, 1972; Till, 2005; Pateman, 2012) and their involvement in the decision-making processes (Williams, 2005). 
The two case-studies, compared in Table 1, follow the bottom-up social structure at different gradients. They have both been built through democratic processes, considering citizen needs and requirements in the whole process though face-to-face meetings and forums. The equilibrium in the triangle relationship_citizens' cooperation, politicians, and architects-is granted. According to Gromark et al. (2015), the architects of traditional housing follow the developers' requirements without considering the future inhabitants' needs and wishes in the development of the project. This does not happen in cohousing.

As mentioned earlier, Casa Malta was born under the 'Hitas' concept, which regulates for 30 years the condition of plot leases or property resale and which does not allow a tenant to have two properties in Hitas system housing. In this 30-year period, the owners cannot sell their apartment at market prices, which provides a non-speculation approach to housing and prevents large investors from speculating with public land. The Hitas concept is an incentive to maintain middle class wageearning families by keeping the price of housing above speculative and lucrative possibilities (Korpela, 2012; Hitas Helsinki, 2019). In conclusion, these examples of collaborative housing policies play a relevant role in avoiding traditional speculative housing developers and consequently ensures affordable housing costs. These housing policies propose an alternative system to the rent/ownership duality.

Table 2. Comparison of the two case-studies social and economic factors

\begin{tabular}{|c|c|c|}
\hline \multicolumn{3}{|c|}{ Social and ecological factors } \\
\hline & Community A (Kalkbreite) & Community B (Casa Malta) \\
\hline $\begin{array}{l}\text { Construction } \\
\text { framework }\end{array}$ & $2012-2014$ & $2010-2013$ \\
\hline Tenure & $\begin{array}{l}\text { Affordable Rent. } \\
\text { Non-profit cooperative }\end{array}$ & $\begin{array}{l}\text { Home ownership and it's a co-development } \\
\text { In Finland } 68 \% \text { is ownership (Laine et al, } \\
\text { 2018) }\end{array}$ \\
\hline Type of leased-plot & $\begin{array}{l}\text { lease on the city-owned land } \\
\text { building permit of } 62 \text { years (usual legal } \\
\text { period in this type of agreements). This } \\
\text { can be followed by an extension of } 2 \times 15 \\
\text { years. }\end{array}$ & $\begin{array}{l}\text { lease on the city-owned land } \\
60 \text { years - Hitas system }\end{array}$ \\
\hline $\begin{array}{l}\text { Decision making } \\
\text { process }\end{array}$ & Consensus & Consensus \\
\hline Household type & $\begin{array}{l}\text { Multigenerational, families, couples, } \\
\text { children, senior, students }\end{array}$ & $\begin{array}{l}\text { Multigenerational, families, couples, } \\
\text { children, senior, students }\end{array}$ \\
\hline Age range & 0 to 70 & 0 to 70 \\
\hline $\begin{array}{l}\text { Residents involvement } \\
\text { and participation }\end{array}$ & $\begin{array}{l}\text { Resident/architect/developer } \\
\text { "partnership" }\end{array}$ & $\begin{array}{l}\text { Resident-led development and } \\
\text { management of everything }\end{array}$ \\
\hline $\begin{array}{l}\text { Organized communal } \\
\text { meals }\end{array}$ & $\begin{array}{l}\text { Meals (Every day in 'grosshaushalt') } \\
\text { Social events (variable per month) }\end{array}$ & $\begin{array}{l}\text { Quotidian common dinners ( } 3 \text { per week), } \\
\text { common parties, cultural events, yard sales, } \\
\text { small scale gymnastics }\end{array}$ \\
\hline Employment estatus & Working and studying & Majority working \\
\hline Education & Diversity education average & Higher education \\
\hline Income & $\begin{array}{l}\text { Diversity of income since there is a high } \\
\text { variability in tenure and spatial options }\end{array}$ & Medium-High income \\
\hline
\end{tabular}

Source: Rental terms Kalkbreite and author authorized interviews realized in both case-studies and on-site field research between 2015 and 2019.

ACE, 15 (4.3) CC BY-ND 3.0 ES | UPC Barcelona, Spain | Collaborative Designing of Communities. Helsinki and Zurich 


\subsection{Shared spaces}

Shared spaces are considered as the "soft edges" (Gehl, 1986) of residential areas, including porches, verandas, semi-private or front courtyards. They have a strong meaning from a sociological point of view. According to Horelli (2013), shared space plays a triple role-it represents an arena of action, it produces multiple meanings depending on the community and it serves as a medium of integration or disintegration.

Casa Malta and Kalkbreite projects both pursue this triple role, although they have different distributions of shared space. Casa Malta's shared spaces are located on the ground floor and on the rooftop. Meanwhile, Kalkbreite's shared spaces are heterogeneously distributed around the whole building on different floors. It has a central park-courtyard (see figure 8) that is open to the public from 8 am to 8 pm, which serves as the perimeter of the cover streets and leads to the other shared spaces in the building, such as the cluster space with shared kitchens.

Figure 8. Kalkbreite cooperative ground floor plan
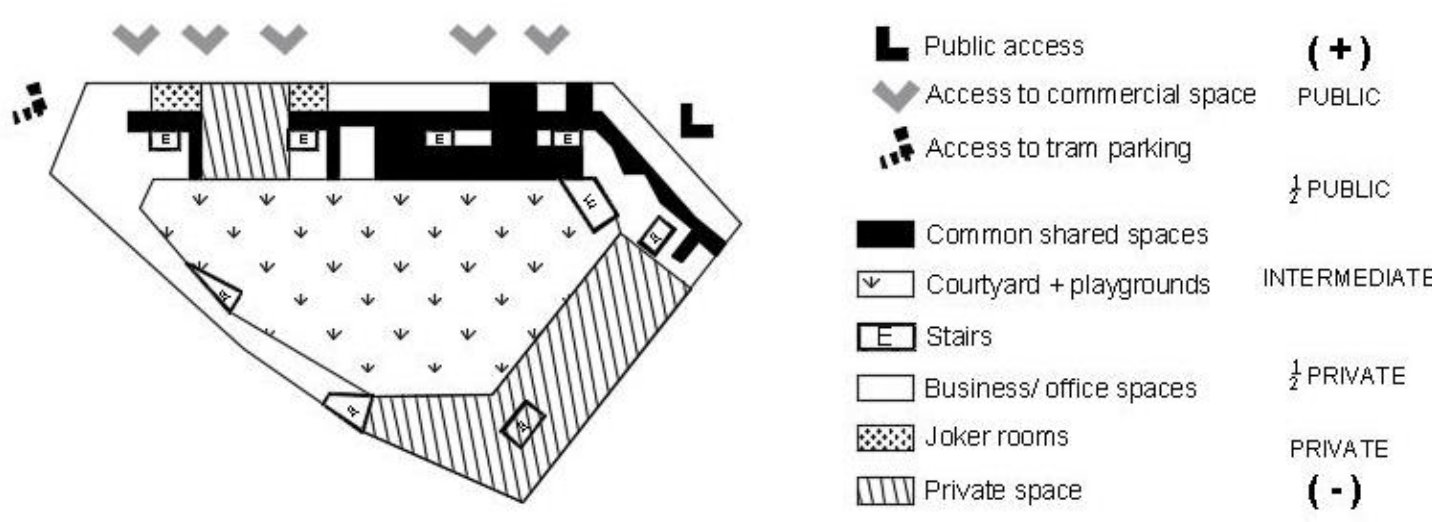

Source: Line drawing by the author from fieldwork in 2015.

In light of the communal spatial analysis by Joanna Williams (2005) based on a compared case-study methodology though different parameters, both projects aim at ecological integration in all aspects at private, intermediary, and public levels (Horelli and Vepsä, 1994). For example, the Kalkbreite cooperative is a car-free community while Casa Malta is a passive building. Another example in the Kalkbreite cooperative is the decision to calculate the density of a single dwelling based it on the number of people per total sqm instead of per residential urban area in hectare (D/ha). According to Schindler (2016), this calculation and its consequent extrapolation to the design project seem to be a more accurate way to quantify and hold the range of lifestyles that might develop in the building.

Finally, in both projects the shared spaces demonstrate the convenience of developing collaborative housing from a sociological and ecological point of view. The users benefit from several advantages in the management of their everyday life and in the reduction of housing cost (as can be read in Table 1). In table 2, both communities are analysed according to 22 parameters, from a descriptive, quantitative and qualitative perspective. This analysis reveals the need to approach the project with a rigorous previous analysis of its "genius loci" a depending of user's needs, since there cannot be a universal recipe apart from key specific parameters. 
Table 2. Comparison of the two case-studies design

\begin{tabular}{|c|c|c|}
\hline & Community $A$ (Kalkbreite) & Community $B$ (Malta) \\
\hline Location & Urban centre > On railways. & Urban centre > new neighbourhood \\
\hline Climate region & Alpine tundra climate ET & Subartic climate Dfc \\
\hline Average Ta & 19 to $\mathrm{O}$ C & 170 to $-60 \mathrm{C}$ \\
\hline $\begin{array}{l}\text { Current population } \\
\text { size }\end{array}$ & 251 & 180 \\
\hline $\begin{array}{l}\text { № units/families } \\
\text { (Variable) }\end{array}$ & 88 & 61 \\
\hline $\begin{array}{l}\text { Total private out of } \\
\text { total }\end{array}$ & $7000 / 13,226$ & $5000 / 6000$ \\
\hline $\begin{array}{l}\text { Average size of } \\
\text { dwellings (sqm) }\end{array}$ & $35-350$ & $40-150$ \\
\hline Diversity of dwellings & $\begin{array}{l}1-4,5-6,7-8 \text { bedroom flat, Flat-shares, } \\
\text { cluster housing, joker rooms }(27-29 m 2 \text {, } \\
\text { with only bathroom) a communal home } \\
\text { for } 50 \text { people }\end{array}$ & $\begin{array}{l}\text { Vary from studios of >40sqm to } 150 \mathrm{sqm} \\
\text { two-storey apartments }\end{array}$ \\
\hline $\begin{array}{l}\text { Size of indoor } \\
\text { communal space/out } \\
\text { of total (sqm) }\end{array}$ & $\begin{array}{l}572 \text { (shared use) } 4944 \text { / 13,226 (mixed- } \\
\text { use program public-business \& culture) }\end{array}$ & $550 / 5700$ \\
\hline $\begin{array}{l}\text { Size of external } \\
\text { communal space/out } \\
\text { of total (sqm) }\end{array}$ & 2500 sqm -public square & 140 terrace rooftop \\
\hline Layout & Hybrid building into a courtyard & Block \\
\hline Ecology integration & $\begin{array}{l}\text { A big common elevated courtyard in the } \\
\text { centre of the building with orchards, park } \\
\text { and playgrounds. There are some } \\
\text { balconies in the shared spaces as well as } \\
\text { private units. }\end{array}$ & $\begin{array}{l}\text { It is a passive building. It has also a rooftop } \\
\text { terrace common for all residents with three } \\
\text { saunas instead of a sauna per apartment. }\end{array}$ \\
\hline $\begin{array}{l}\text { Security, 'Eyes of the } \\
\text { street' (Jacobs, 1965) }\end{array}$ & Yes & Yes \\
\hline Cars allowed & No, Car-free community & $\begin{array}{l}\text { Yes, but reduced. They have a shared-car. } \\
\text { Malta has only a parking hall for } 24 \text { cars. }\end{array}$ \\
\hline $\begin{array}{l}\text { Shared walkways } \\
\text { linking activities sites }\end{array}$ & Yes & Yes \\
\hline $\begin{array}{l}\text { Transition between } \\
\text { spaces }\end{array}$ & Gradual & Gradual \\
\hline Commercial spaces & $\begin{array}{l}\text { Yes - Ground floor with cinema, shops, } \\
\text { restaurant. }\end{array}$ & Yes - Ground floor, shops. \\
\hline $\begin{array}{l}\text { Intermediate spaces } \\
\text { outside private }\end{array}$ & Yes- interior promenade & $\begin{array}{l}\text { Yes- transitional zones located in the } \\
\text { access and common areas. }\end{array}$ \\
\hline $\begin{array}{l}\text { Types of shared } \\
\text { spaces }\end{array}$ & $\begin{array}{l}\text { Communal dining room and kitchen, } \\
\text { Paper recycling, } 300 \text { walk-bike parking } \\
\text { spaces, atelier, music studio, day-care } \\
\text { nursery, laundry, hall-foyer, café, } \\
\text { multipurpose space }\end{array}$ & $\begin{array}{l}\text { Shared kitchen, storage space, multi- } \\
\text { purpose hall, library corner, laundry, drying } \\
\text { rooms, three saunas, a den, shielded roof } \\
\text { garden and open-air terraces in rooftop }\end{array}$ \\
\hline $\begin{array}{l}\text { Quality and adequacy } \\
\text { of shared spaces }\end{array}$ & $\begin{array}{l}\text { Living and accessibility area modern } \\
\text { (2014) }\end{array}$ & Living and accessibility area modern (2014) \\
\hline $\begin{array}{l}\text { Flexibility } \\
\text { (developed in point } \\
\text { 4.3) }\end{array}$ & $\begin{array}{l}\text { There is a multipurpose space as well as } \\
\text { the central outdoor courtyard that can be } \\
\text { used for different activities }\end{array}$ & $\begin{array}{l}\text { Shared living room flexible for different } \\
\text { activities and meetings, located in ground } \\
\text { floor }\end{array}$ \\
\hline
\end{tabular}




\begin{tabular}{|l|l|l|}
\hline Morphology buildings & $\begin{array}{l}10 \text { storeys in one elevated courtyard } \\
\text { building. It is a "mat-hybrid housing" in a } \\
\text { tram infrastructure }\end{array}$ & 10 storeys in one "high rise" building \\
\hline $\begin{array}{l}\text { Location of shared } \\
\text { spaces }\end{array}$ & In every floor (figure 6) & Ground Floor and rooftop. (figure 6) \\
\hline
\end{tabular}

Source: Own elaboration from rental terms Kalkbreite Cooperative website (2012-2018), Ibrahim and Müller, 2014; Korpela, 2012 and Author on-site field research between 2015 and 2019.

\subsection{Spatial flexibility for the users changing needs over time}

A flexible space was already a key point in building "family Hotels" (Myrdal, 1932), such as San Remo complex or the Waldorf-Astoria hotel in the United States. Planning the presence of a so-called "habitation unit" made a flexible space an ordinary project component in these apartment-hotels. A flexible distribution was generated by building a room between two different apartments, allowing the inhabitants to enlarge or take in their interior domestic space. The concept of an 'all-rounder' room such as "habitation unit" is present also in the Kalkbreite neighbourhood. The community and their architects have named this the "joker room", which was explained by a management board member (Wolf, 2015), as highlighted in Figure 9 in black solid colour.

Figure 9. Kalkbreite cooperative and 'joker room'
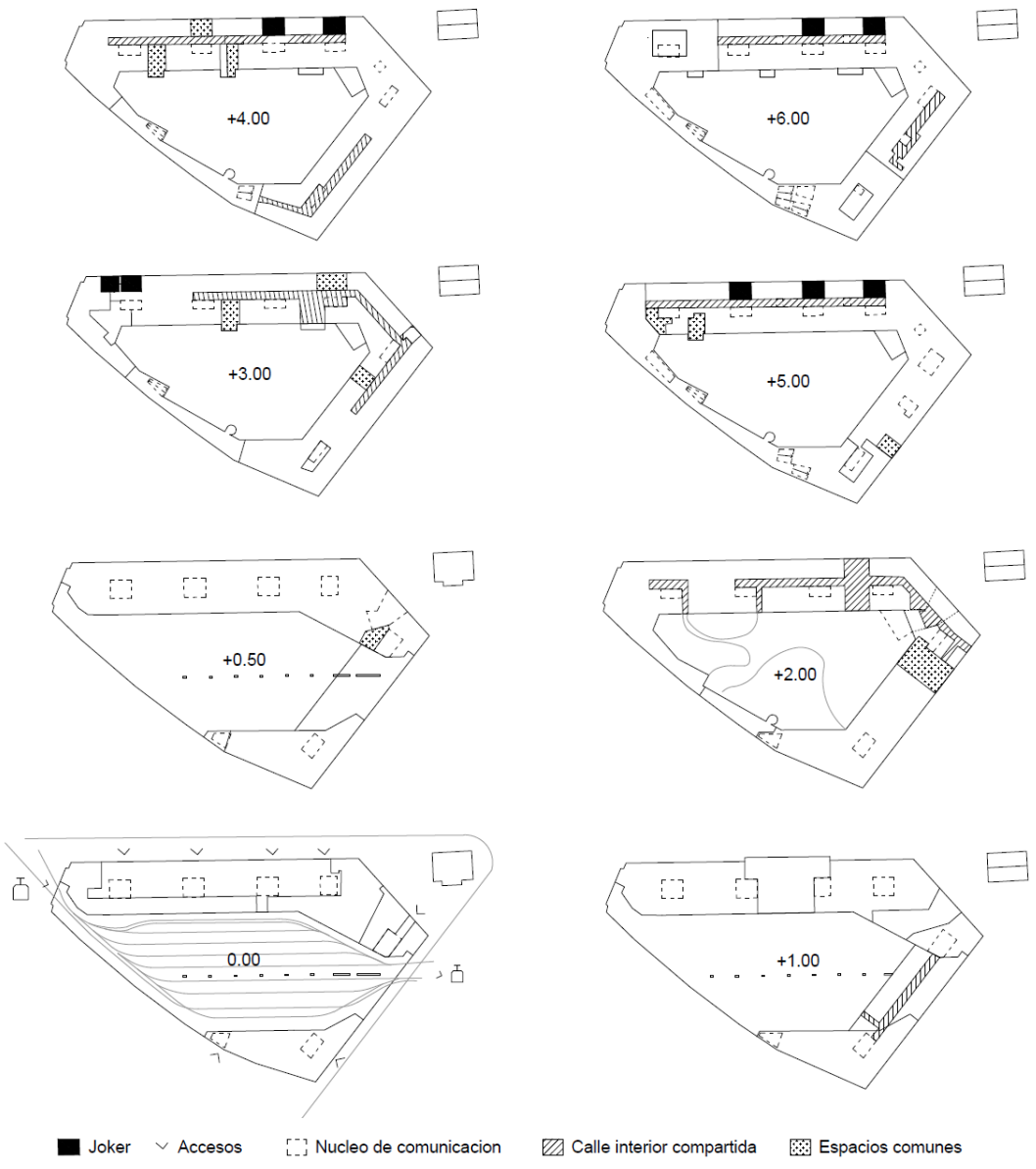

Calle interior compartida Espacios comunes $\checkmark$ Tranvia paso

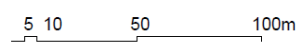

Source: Line drawing by the author from Wolf et al, 2015 (p.873), De Jorge-Huertas (2019) and fieldwork in 2015.

ACE, 15 (4.3) CC BY-ND 3.0 ES | UPC Barcelona, Spain | Collaborative Designing of Communities. Helsinki and Zurich 
The Kalkbreite joker room is a 27 to 29 square meters room with a bathroom but no kitchen, which can be rented out from 6 months up to 4 years and can be also rented out as a hotel room. Therefore, space flexibility is an option to polyvalence, making the infrastructure 'profitable' if needed. The Kalkbreite rental terms eventually state that the number of people living in individual rooms must be the same as the number of the people living in apartments to generate a social mix and reduce gentrification. While Forlano (2016) says that 'it is increasingly important for the field of design to find ways to move beyond human needs and the human experience of the world, particularly in light of environmental and economic crisis', in this work the participative design and spatial flexibility is also present in the Casa Malta project. For example, the shared space located on the ground floor was pre-planned and built considering the possibility of being converted into a restaurant if the community later decided to rent or sell the space. Consequently, both case-studies adopt the concept of using flexible space to easily adapt to the users changing needs over time. Spatial flexibility can be a convenient component for a community and supports the alternative housing approach of collaborative housing.

The "micro" masterpiece of space flexibility, the "joker room", is represented in figure 9, and more in detail in Figure 10. This artifact is a piece formed by a bathroom and a space of approximately 2527sqm. In the figure 10, nine different hypothetical configurations are represented considering solar orientation. Below the hypothesis of the "joker room" (in green colour) in between two dwellings allowing change and flexibility. In the centre, the joker room is located, left and right sides are showing two different possibilities if the "joker room" is absorbed by the adjoining dwellings.

Figure 10. Performance of the "joker room"
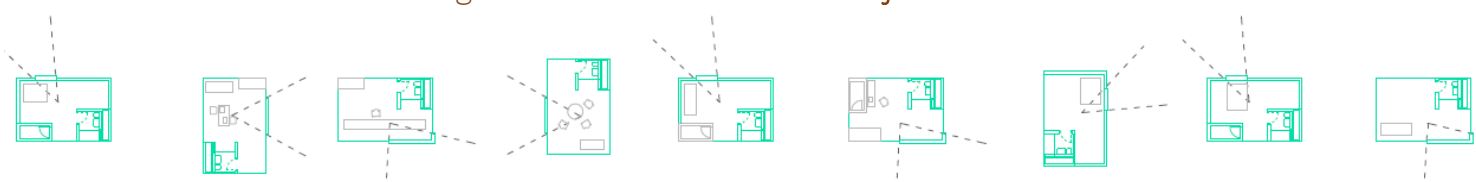

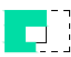
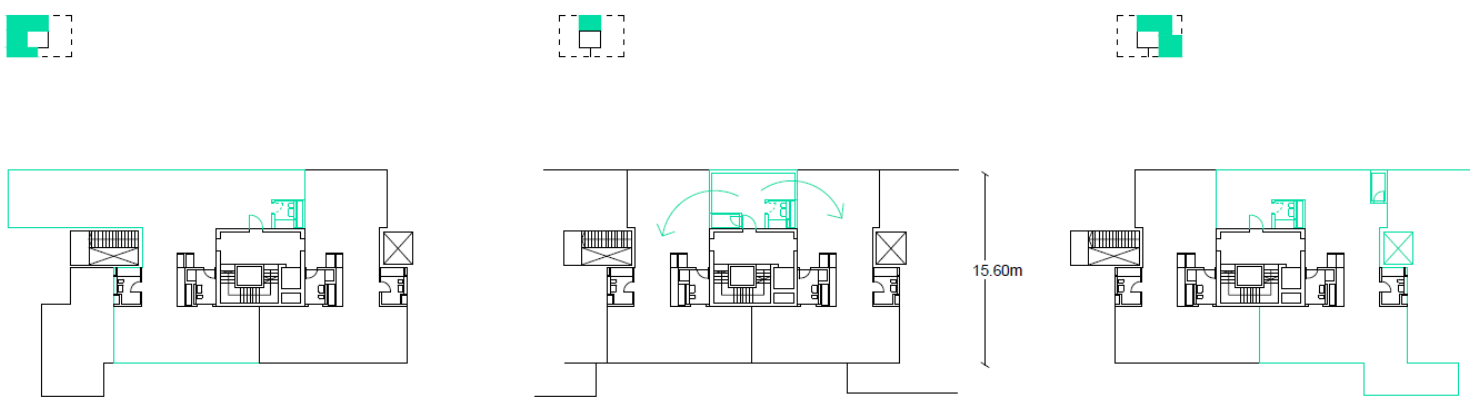

Source: Line drawing by the author.

\section{Conclusions}

Collaborative housing in the form of hybrid housing cooperatives and multigenerational cohousing, appears to reduce the influence of profit-seeking strategies in real estate markets. Cohousing projects represent an important alternative form of living that is able to meet the needs and wishes of many people today. However, a user-centred design and the user's involvement in the decision-making process, as well as the participative approach based on civic engagement are all essential. The commons (Ostrom, 1990) and self-governance as a sharing concept are growing in importance in architectural and urban design to promote the architecture of participation. However, one of the 
strongest limitations is directly related with the policies adopted by the city. If policy makers do not provide certain regulations (ex. Provide lease of plot, new hybrid programs, avoid zoning of urban plots), these models of projects can't be adopted neither implemented.

This research aimed to identify the key points of these alternative approaches for housing. Several factors have been analysed (e.g. spatial distribution, organisation, and affordability) to determine how they influence social innovation, including generating an "intermediary level" both in between public and private and in between market and affordable housing, and clustering of shared spaces; taking advantage of the existing infrastructures; combining different uses in addition to residential; creating "joker rooms" to promote flexibility, polyvalence and growth in domestic space according to the user's needs and requirements; developing different housing policies, such as 'Hitas', to reduce housing speculation; and promoting the tenants' involvement (such as in Casa Malta and Kalkbreite) in community-oriented developments.

\subsection{Recommendations}

These recommendations are intended to target different actors and multi-stakeholders in the collaborative designing of communities. Regarding policy makers and housing providers, it is recommended to regulate the rent prices, such as "Casa Malta" example with the "Hitas system" in Finland and avoiding the sale of public housing could improve the stability of the housing unaffordable current situation. In addition, plots of land in the inner city could be provided to develop non-profit cooperatives and avoid gentrification, as the case-study "Kalkbreite" in Zurich, Switzerland.

The third recommendation is to include the citizen's active participation in any project, which should be always considered. This point has been analysed in both constellations of actors-network in Kalkbreite and Casa Malta. The fourth recommendation focus in citizens and housing designers, is to work in a multidisciplinary group, including at least a sociologist to do the interviews and to interact as a hinge between the architecture studio and the users.

The final recommendation for housing researchers, when possible, should be to put together successful case-studies into an open access "toolkit" online database, able to grow with new examples. The conclusions taken from this comparative case-study research suggest that this alternative housing approach could be used to address the problems in an existing urban context with specific reference to vacant housing stock, unaffordable housing and abandoned buildings.

\section{Acknowledgements}

This research is supported by the Spanish Ministry of Education, Culture, and Sports (MECD) under a four-year research contract [FPU MECD 2015/00791] and it is part of the third chapter of the author's doctoral thesis: "Esferas, Umbrales e Infraestructuras". In addition, the author wants to thank Salla Korpela for the guided tour at Casa Malta in Helsinki, Lisa Horelli for her comments in a previous version of this article in 2019, the communications officers of Genossenschaft Kalkbreite in 2018, Valerie and Aline, for their kindness in answering all questions and finally the editor and the two anonymous reviewers for their constructive comments.

Conflict of interests: Author declares no conflict of interests. 


\section{Bibliography}

Arnstein, S. (1969). A ladder of citizen participation. Journal of the American Institute of Planners, 35(4), 216-224. DOI: http://dx.doi.org/10.1080/01944366908977225

Balmer, I. and J.D. Gerber. (2017). Why are housing cooperatives successful? Insights from Swiss affordable housing policy. Housing Studies, 361-385. DOI: http://dx.doi.org/10.1080/02673037.2017.1344958

Bagnoli, A. (2009). Beyond the standard interview: The use of graphic elicitation and arts-based methods. Qualitative Research, 9(5), 547-570. DOI: http://dx.doi.org/10.1177/1468794109343625

Boonstra, B. (2016). Mapping trajectories of becoming: four forms of behavior in co-housing initiatives. The Town Planning Review. 87(3), 275-296.

Boucsein, B. and Seidel, T. (2015). Open Building as a Principle of Cooperative Housing. Proceedings of the Open Building conference, Switzerland, 2015, ETH Zurich, Zürich, 1-14. Summary retrieved from: https://openbuilding2015.arch.ethz.ch/conference-proceedings.html

Bresson, S. and S. Denèfle. (2015). Diversity of Self-Managed Co-Housing Initiatives in France. Urban Research and Practice 8(1), 5-16. DOI: http://dx.doi.org/10.1080/17535069.2015.1011423

Cabré, E. and Andrés, A. (2018). La Borda: a case study on the implementation of cooperative housing in Catalonia. International Journal of Housing Policy, 18(3), 412-432. DOI: http://dx.doi.org/10.1080/19491247.2017.1331591

Carreiro-Otero, M. y López-González. C. (2019). La cocina moderna en la vivienda colectiva española a través de los concursos de arquitectura del período 1929- 1956. ACE: Architecture, City and Environment, 13(39): 183-210. DOI: http://dx.doi.org/10.5821/ace.13.39.5979

Charta der gemeinnützigen Wohnbauträger in der Schweiz. https://www.wbg-schweiz.ch/ (Carta de promotores residenciales sin fines de lucro en Suiza)

De Carlo, G. (1972). The architecture of participation. The Melbourne Architectural papers. The Royal Australian Institute of Architects, 1-34.

De Jorge-Huertas, V. (2019b). Baugruppen. Innovation through collaborative infrastructures. TECHNE - Journal of Technology for Architecture and Environment, (17), 171-182. DOI: http://dx.doi.org/10.13128/Techne-23879

De Jorge-Huertas, V. (2018a). Mat-hybrid housing: Two case studies in Terni and London. Frontiers of Architectural Research, 7(3), 276-291. DOI: http://dx.doi.org/10.1016/j.foar.2018.05.002

De Jorge-Huertas, V. (2018b). Focusing on retrofit cohousing. Tactics for future implementation. In: More together, more apart: Migration, densification, segregation in Proceedings of the European

ACE, 15 (4.3) CC BY-ND 3.0 ES | UPC Barcelona, Spain | Collaborative Designing of Communities. Helsinki and Zurich 18 Pioneers. DOI: http://dx.doi.org/10.5821/ace.15.43.9012 
Network for Housing Research in Uppsala, Sweden. Summary retrieved from: https://www.researchgate.net/publication/334361998 Focusing on Retrofit Cohousing Tactics for Future Implementation

De Jorge-Huertas, V. (2019). Esferas, Umbrales e Infraestructuras. (Doctoral thesis). Escuela Técnica Superior de Arquitectura, Universidad de Alcalá, Madrid.

Díaz, C. et al. (2019) Intervenciones de rehabilitación en grandes conjuntos habitacionales construidos durante el periodo 1950-1975. ACE: Architecture, City and Environment, 14(41): 11-34. DOI: http://dx.doi.org/10.5821/ace.14.41.6538

Droste, C. (2015). German co-housing: an opportunity for municipalities to foster socially inclusive urban development? Urban Research \& Practice, 8(1), 79-92. DOI: http://dx.doi.org/10.1080/17535069.2015.1011428

Falkenstjerne Beck, A. (2019). What Is Co-Housing? Developing a Conceptual Framework from the Studies of Danish Intergenerational Co-Housing. Housing, Theory and Society, DOI: http://dx.doi.org/10.1080/14036096.2019.1633398

Forlano, L. (2016). Decentring the Human in the Design of Collaborative Cities. Design Issues, 32(3), 42-54. DOI: http://dx.doi.org/10.1162/DESI a 00398

Frampton, K. (1999). Mega form as urban landscape. Michigan, USA: Mass Market Paperback.

Hayden, D. (1980). What Would a Non-Sexist City Be Like? Speculations on Housing, Urban Design, and Human Work. Signs: Journal of Women in Culture and Society, 3, 170-187. DOI: http://dx.doi.org/10.1086/495718

Hitas Helsinki official website. https://www.hel.fi/kv/hitas-fi

Hofer, A.; Hugentobler, M. and Simmendinger, P. (2015). More than Housing: Cooperative Planning - A Case Study in Zurich. Milan, Italy: Bompiani.

Hofer, A. (2017). A city for people. In C. Kries; Müller, M; Niggli, D; Ruby, A and Ilka Ruby (Ed.), Together! The New Architecture of the collective (pp. 57-65). Berlin, Germany: Ruby Press.

Horelli, L. (2013). The role of shared space for the building and maintenance of community from the gender perspective - a longitudinal case study in a neighborhood of Helsinki. Social Sciences Directory, 2(3), 1-20.

Horelli, L. and Vepsa, K. (1994). In Search of Supportive Structures for Everyday life, in Altman, I, and Churchman, A. (Ed.), Women and Environment (pp. 201-226). New York, NY, USA: Plenum Press.

Ibrahim, M. and S. Müller, (2014), Case study. Kalkbreite Zurich. Ljubljana, Slovenia: Future city SI.

Koti Kaupungissa. http://www.hemistan.fi/

ACE, 15 (4.3) CC BY-ND 3.0 ES | UPC Barcelona, Spain | Collaborative Designing of Communities. Helsinki and Zurich 19 Pioneers. DOI: http://dx.doi.org/10.5821/ace.15.43.9012 
La col y la ciutat invisible. 2018. Habitar en comunidad. España, Barcelona: Arquia, Fundación Caja de Arquitectos.

Laine, M. et al. (2018). Bricolage in Collaborative Housing in Finland: Combining Resources for Alternative Housing Solution. Housing, Theory and Society. 37:1, 101-117, DOI: $\underline{\text { http://dx.doi.org/10.1080/14036096.2018.1492438 }}$

Lang, R. et al. (2018). Collaborative Housing Research (1990-2017): A Systematic Review and Thematic Analysis of the Field, Housing, Theory and Society. DOI: http://dx.doi.org/10.1080/14036096.2018.1536077

FSO (2017) Federal statistical office Switzerland. Retrieved from: https://www.bfs.admin.ch/bfs/en/home/statistics/construction-housing/dwellings/housingconditions/tenants-owners.html

Gehl, J. (1986). Soft edges in residential streets. Scandinavian Housing and Planning Research, 3(2),

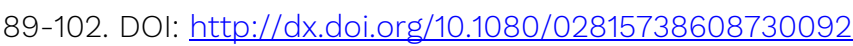

Gromark, S. et al. (2015). Ways of Residing in Transformation: Interdisciplinary Perspectives. London, United Kingdom: Routledge.

Hediger, E. (2019) We should live in grand hotels. Hello Zurich. Stories and Specials. 07.03.2019. Retrieved from: https://www.hellozurich.ch/en/news/kalkbreite.html

Jarvis, H. (2015). Towards a Deeper Understanding of the Social Architecture of Co-Housing: Evidence from the UK, USA and Australia. Urban Research and Practice. 8(1), 93-105. DOI: http://dx.doi.org/10.1080/17535069.2015.1011429

Jakobsen, P. and H. Gutzon. (2018). An alternative for whom? The evolution and socio-economy of Danish cohousing. Urban Research \& Practice. DOI: http://dx.doi.org/10.1080/17535069.2018.1465582

Kalkbreite Cooperative. (10 December 2012). Kalkbreite Manual - an example of participation. Kalkbreite. Zúrich.

Kalkbreite Cooperative. (20 November 2015). Projektdokumentation August 2014. Kalkbreite. Zúrich. Retrieved on 30.12.2016,

Korpela, S. (2012). Casa Malta: A Case Study of a Contemporary Co-Housing Project in Helsinki. Built Environment. 38(3), 336-344. DOI: http://dx.doi.org/10.2148/benv.38.3.336

Koti Kaupungissa association. (2018). http://www.hemistan.fi/

Marcuse, P. and D. Madden. (2016). In defense of housing: The Politics of Crisis. London, UK: Verso Books.

ACE, 15 (4.3) CC BY-ND 3.0 ES | UPC Barcelona, Spain | Collaborative Designing of Communities. Helsinki and Zurich 20 Pioneers. DOI: http://dx.doi.org/10.5821/ace.15.43.9012 
McCamant, K. and C. Durrett. (1994). Cohousing: a contemporary approach to housing ourselves. Berkeley California, USA: Ten Speed Press.

Myrdal, A. (1932). Kollektiv bostadsform. Tiden. Retrieved from: https://stockholmskallan.stockholm.se/post/28430

Ostrom, E. (1990). Governing the Commons: The Evolution of Institutions for Collective Action. Cambridge, UK: Cambridge University Press.

Parés, M., el al. (2017). 'Challenging Collaborative Urban Governance under Austerity: How Local Governments and Social Organizations Deal with Housing Policy in Catalonia (Spain)'. Journal of Urban Affairs O(0), 1-19. DOI: http://dx.doi.org/10.1080/07352166.2017.1310531

Pateman, C. (2012). Participatory Democracy Revisited. Perspectives on Politics. 10(1). DOI: http://dx.doi.org/10.1017/S1537592711004877

Prosser, J. (2008). Visual Methodology: Towards a More Seeing Research. Handbook of Qualitative Research. London, United Kingdom: Sage.

Rogel, L; Corubolo, M; Gambarana, C; Omegna, E. (2018). Cohousing. L'arte di vivere insieme. Principi, Esperienze e numeri dell'abitare collaborativo. La prima mappatura in Italia. A cura di Housing Lab, Milan, Italy: Altreconomia.

Sánchez de Madariaga, I. and Roberts, M. (2016). Fair Shared Cities. The Impact of Gender Planning in Europe. USA: Routledge.

Sanguinetti, A. (2015). Diversifying cohousing: The retrofit model. Journal of architectural and planning research, 32(1), 68-90.

Sandstedt, E. and S. Westin. (2015). Beyond Gemeinschaft and Gesellschaft. Cohousing Life in Contemporary Sweden. Housing, Theory and Society, 32(2), 131-150. DOI: http://dx.doi.org/10.1080/14036096.2015.1011687

Sepe, M. (2014). Urban transformation, socio-economic regeneration and participation: two cases of creative urban regeneration, International Journal of Urban Sustainable Development, 6:1, 20-41, DOI: http://dx.doi.org/10.1080/19463138.2013.866560

Scheller, D. and Thörn, H. (2018). Governing 'sustainable urban development' through self-build groups and cohousing: the cases of Hamburg and Gothenburg. International Journal of Urban and Regional Research, 42(5), 914-933. DOI: http://dx.doi.org/10.1111/1468-2427.12652

Schindler, S. (2014). Housing and the Cooperative Commonwealth. Places Journal. DOI: http://dx.doi.org/10.22269/141022

Till, J. (2005). The Negotiation of Hope. In Blundell Jones, Petrescu, Till (Ed.), Architecture and Participation (pp. 25-44), London, United Kingdom: Routledge.

ACE, 15 (4.3) CC BY-ND 3.0 ES | UPC Barcelona, Spain | Collaborative Designing of Communities. Helsinki and Zurich 21 Pioneers. DOI: http://dx.doi.org/10.5821/ace.15.43.9012 
TEPSIE. (2014). Social innovation theory and research: A summary of the findings from TEPSIE. Brussels: European Commission, DG Research. Retrieved from: https://iupe.files.wordpress.com/2015/11/tepsie-research report final web.pdf

Tummers, L. (2015). The re-emergence of self-managed co-housing in Europe: A critical review of cohousing research. Urban studies, 53(10), 1-18. DOI: http://dx.doi.org/10.1177/0042098015586696

Van der Bijl-Brouwer, M. and K. Dorst. (2017). Advancing the strategic impact of human-centred design. Design Studies, 53, 1-23. DOI: http://dx.doi.org/10.1016/j.destud.2017.06.003

Vestbro, D. U. ed. (2010). Living together - Cohousing Ideas and Realities Around the World. Proceedings from the international collaborative housing conference in Stockholm. Royal Institute of Technology, Stockholm. Retrieved from: http://kollektivhus.se/wpcontent/uploads/2017/06/Livingtogetherwebb-1.pdf

Vestbro, D. U. and Horelli, L. (2012). Design for gender equality - the history of cohousing ideas and realities. Built Environment. 3, 315-335. DOI: http://dx.doi.org/10.2148/benv.38.3.315

Vestbro, D.U. (2000). From collective housing to co-housing. A summary research. Journal of Architectural and Planning Research, 17(2), 164-177. Retrieved from: https://www.jstor.org/stable/43030534?seq=1\#page scan tab contents

Verhetsel, A. et al. (2017). Housing preferences among students: collective housing versus individual accommodations? A stated preference study in Antwerp (Belgium). Journal of Housing and the Built Environment. 32, 449-470. DOI: http://dx.doi.org/10.1007/s10901-016-9522-5

Williams, J. (2005). Designing Neighbourhoods for Social Interaction: The Case of Cohousing. Journal of Urban Design, 10(2), 195-227. DOI: http://dx.doi.org/10.1080/13574800500086998

Werczberger, E. (1997). Home ownership and rent control in Switzerland. Housing Studies, 12(3), 337353. DOI: http://dx.doi.org/10.1080/02673039708720900

Wolf, S. (2015). Wohn-und Gewerbebau Kalkbreite in Zürich. DETAlL. Magazine of Architecture + Construction Details, 868-880. 